\title{
Investigation of penetratin peptides. Part 2. In vitro uptake of penetratin and two of its derivatives
}

\author{
TAMÁS LETOHA, ${ }^{a *}$ SZILVIA GAÁL, ${ }^{a}$ CSABA SOMLAI, ${ }^{a}$ ZSOLT VENKEI, ${ }^{b}$ HRISTOS GLAVINAS, ${ }^{c}$ ERZSÉBET KUSZ, ${ }^{c}$ \\ ERNÖ DUDA, ${ }^{c}$ ANDRÁS CZAJLIK, ${ }^{d}$ FERENC PETÁK ${ }^{\ominus}$ and BOTOND PENKEa \\ a Department of Medical Chemistry, University of Szeged, H-6720 Szeged, Hungary \\ b Department of Medical Biology, University of Szeged, H-6720 Szeged, Hungary \\ c Institute of Biochemistry, Biological Research Center of the Hungarian Academy of Sciences, H-6726 Szeged, Hungary \\ d Department of Organic Chemistry, Eötvös Loránd University, H-1518, Budapest, Hungary \\ e Department of Medical Informatics, University of Szeged, H-6720 Szeged, Hungary
}

Received 22 December 2004; Revised 23 December 2004; Accepted 3 March 2005

\begin{abstract}
As endocytic uptake of the Antennapedia homeodomain-derived penetratin peptide (RQIKIWFQNRRMKWKK) is finally being revealed, some of the early views about penetratin need to be reconsidered. Endocytic uptake seems to contradict the indispensability of tryptophans and also the minimum length of 16 amino acid residues for efficient internalization. To revise the membrane translocation of penetratin, two penetratin analogs were designed and synthesized: a peptide in which tryptophans were replaced by phenylalanines (Phe ${ }^{6,14}$-penetratin, RQIKIFFGNRRMKF KK) and a shortened analog (dodeca-penetratin, RQIKIWF$R$-KWKK) made up of only 12 residues. The peptides were fluorescently labeled and applied to live, unfixed cells from various lines. Cellular uptake was analysed by confocal microscopy and flow cytometry. Low temperature or ATP-depletion blocked the intracellular entry of all three penetratin peptides. A decrease in membrane fluidity or cholesterol depletion with methyl- $\beta$ cyclodextrin greatly inhibited peptide uptake, showing the involvement of cholesterol-rich lipid rafts in internalization. Exogenous heparan sulfate also diminished the internalization of penetratin and its derivatives, reflecting the paramount importance of electrostatic interactions with polyanionic cell-surface proteoglycans. The beneficial presence of tryptophans is supported by observations on the decreased cellular uptake of Phe ${ }^{6,14}$-penetratin. The maintained translocational efficiency of dodecapenetratin demonstrates that a thorough understanding of penetratin internalization can yield new penetratin analogs with unaltered translocational abilities.

This study provides evidence on the energy-dependent and lipid raft-mediated endocytic uptake of penetratin and highlights the necessity of revealing those pathways that cationic cell-penetrating peptides employ to enter live cells. Copyright $\odot 2005$ European Peptide Society and John Wiley \& Sons, Ltd.
\end{abstract}

Keywords: cell-penetrating peptides; penetratin; endocytosis; lipid rafts; FITC-labeling; confocal microscopy; flow cytometry

\section{INTRODUCTION}

During the past decade several polypeptides have been shown to traverse biological membranes and transport attached bioactive cargos intracellularly. A wide range of biomolecules such as peptide nucleic acids, oligonucleotides and proteins have been delivered with these cell-penetrating peptides (CPPs) both in vitro and in vivo [1-5]. The Antennapedia homeodomain-derived highly cationic penetratin peptide (RQIKIWFQNRRMKWKK) is one of the most frequently applied CPPs [6-14]. Despite intense research on penetratin, the exact mechanism of its translocation is still not fully understood [6]. Early reports claimed a temperature and endocytosisindependent membrane translocational mechanism [15-17], however, recent mechanistic studies on live, unfixed cells contradict all these by demonstrating the lack of uptake at low temperatures and the involvement

\footnotetext{
* Correspondence to: T. Letoha, Department of Medical Chemistry, University of Szeged, Dóm tér 8, H-6720 Szeged, Hungary; e-mail: tletoha@yahoo.com
}

of endocytosis in the internalization of the peptide [18-21].

As endocytic uptake of penetratin is finally being revealed some of the early views about this peptide have to be revised. Endocytic uptake seems to contradict the indispensability of tryptophans and the minimum length of 16 amino acid residues for efficient internalization. To examine the translocation of penetratin, two penetratin analogs were designed and synthesized: a peptide in which the tryptophans were replaced by phenylalanines ( $\mathrm{Phe}^{6,14}$ penetratin, RQIKIF FQNRRMKF KK) and a shortened analog (dodeca-penetratin, RQIKIWF-R-KWKK) made up of only 12 residues. Dodeca-penetratin was produced by removing Gln8, Asn9, Arg 11 and Met12 from the penetratin sequence.

The first part of this paper published the conformational study of penetratin and the two analogs [22]. This part presents the results of in vitro biological studies with these penetratin peptides. To examine their cellular uptake the peptides were fluorescently labeled with FITC. Fluorescein was selected because 
of the minimum impact on the cellular distribution of fluorescently labeled peptides [21] and because extracellular fluorescence can be quenched by trypan blue [23-27]. Recent studies brought out the importance of maintaining natural conditions to avoid artifactual internalization of CPPs [18-21], thus throughout the studies interference with normal cellular functions was minimized. The in vitro experiments were carried out on live, unfixed cells from various lines at $37^{\circ}$ and $0{ }^{\circ} \mathrm{C}$. Cellular uptake of the fluorescently labeled peptides was investigated with both confocal microscopy and flow cytometry. The energy-dependence of translocation and the role of lipid rafts and cell-surface polyanions in the internalization process was examined. The effect of membrane fluidity was studied on quail CEC-32 fibroblasts and on a murine WEHI 164 cell-line transfected with a lipid-desaturase gene [28]. By applying penetratin and its derivatives in the same experimental settings, it was easy to compare their translocational efficiencies and to reconsider the internalization mechanism of the parent penetratin peptide.

\section{MATERIALS AND METHODS}

\section{Reagents}

Reagents for cell biology including DMEM, MIX-MEM, OptiMEM, RPMI, fetal bovine serum (FCS), chicken serum, heparan sulfate (HS), methyl- $\beta$-cyclodextrin (MCD), sodium azide and 2-deoxy-D-glucose were obtained from Sigma. Trypan blue was purchased from Merck KGaA, Germany.

\section{Peptide Synthesis and Labeling}

Penetratin and its two analogs (Phe $\mathrm{P}^{6,14}$-penetratin and $\operatorname{des}^{8,9,11,12}$-penetratin $=$ dodeca-penetratin) were synthesized with a solid phase method on MBHA-resin using Bocchemistry. Penetratin was synthesized and purified as described elsewhere $[15,16]$.

\section{Characterization of the Two Penetratin Derivatives}

Phe ${ }^{6,14}$-penetratin-amide, RQIKIFFQNRRMKFKK- $\mathrm{NH}_{2}$, was isolated as a single peak after HPLC purification. $R_{\mathrm{t}}=7.36 \mathrm{~min}$ (Luna $5 \mathrm{C} 18$ column; $250 \times 4.6 \mathrm{~mm}$; mobile phase: $80 \%$ acetonitrile in $0.1 \%$ TFA; acetonitrile gradient elution $22 \%-37 \%$ in $15 \mathrm{~min}$; flow rate: $1.2 \mathrm{ml} / \mathrm{min}$; detection: $220 \mathrm{~nm}$ ). $\mathrm{M}+\mathrm{H}^{+}=2169$ (calcd.: 2168).

Dodeca-penetratin-amide, RQIKIWFRKWKK- $\mathrm{NH}_{2}$ was isolated as a single peak after HPLC purification. $R_{\mathrm{t}}=7.36 \mathrm{~min}$ (Jupiter 5 C 18 column; $250 \times 4.6 \mathrm{~mm}$; mobile phase: $80 \%$ acetonitrile in $0.1 \%$ TFA; acetonitrile gradient elution $28 \%-43 \%$ in $15 \mathrm{~min}$; flow rate: $1.2 \mathrm{ml} / \mathrm{min}$; detection: $220 \mathrm{~nm}$ ) $\mathrm{M}+\mathrm{H}^{+}=1718$ (calcd.: 1717).

Fluorescein labeling of these peptides was performed as described by Fülöp et al. [29] using fluorescein isothiocyanate (FITC I). For selective $N$-terminal labeling of the peptides, the $\varepsilon$-amino group of the side chains of lysines were protected with Fmoc-groups. In the first step (regarding penetratin) H-Arg-Gln-Ile-Lys(Fmoc)-Ile-Trp-Phe-Gln-Asn-ArgArg-Met-Lys(Fmoc)-Trp-Lys(Fmoc)-Lys(Fmoc)- $\mathrm{NH}_{2}$ was synthesized on solid phase and isolated as a single peak after HPLC purification. $R_{\mathrm{t}}=26.32 \mathrm{~min}$ (Luna $5 \mathrm{C} 18$ column; $250 \times 4.6 \mathrm{~mm}$; mobile phase: $80 \%$ acetonitrile, $0.1 \%$ TFA; gradient elution from $5 \%$ to $80 \%, 30 \mathrm{~min}$; flow rate $1.2 \mathrm{ml} / \mathrm{min} ; 220 \mathrm{~nm}$ ). $\mathrm{M}+\mathrm{H}^{+}=3137$ (calcd.: 3136). For the labeling, $15 \mathrm{mg}(5 \mu \mathrm{mol})$ of the peptide, dissolved in dimethylformamide $(1 \mathrm{ml})$ and $0.2 \mathrm{M}$ carbonate-bicarbonate buffer $(0.5 \mathrm{ml}, \mathrm{pH}=9.03)$, was allowed to react with $7.5 \mathrm{mg}(20 \mu \mathrm{mol})$ of fluorescein isothiocyanate isomer I (Sigma) under stirring for $24 \mathrm{~h}$ at room temperature in the dark. The reaction mixture was concentrated in vacuo to dryness then lyophilized from acetonitrile-water solvent mixture. Deprotection of the side chain protecting groups was performed by $20 \%$ piperidinedimethylformamide $(4 \mathrm{ml})$ by stirring the reaction mixture for $20 \mathrm{~min}$ at room temperature. After lyophilization, the resulting fluorescein isothiocarbamoyl peptide (FTC-penetratin) was dissolved in acetonitrile $(1 \mathrm{ml})$, acidified to $\mathrm{pH}=2$ by trifluoroacetic acid, diluted to $10 \mathrm{ml}$ by adding distilled water, filtered off and purified by RP HPLC on a Knauer instrument using a BST SI-100-S 10 C18 column $(25 \times 240 \mathrm{~mm})$. Elution: acetonitrile gradient from $24 \%$ to $68 \%$ in $90 \mathrm{~min}$, flow rate: $3.5 \mathrm{ml} / \mathrm{min}$, detection: $220 \mathrm{~nm}$. Eluent system: A: $0.1 \% \mathrm{TFA}$, B: $80 \%$ acetonitrile in $0.1 \%$ TFA.

Purity control of the fluorescein-labeled peptides was performed using analytical HPLC on an LKB Bromma 2150 instrument. Conditions for FTC-penetratin: Lichrosorb 10RP 18 column $(250 \times 4.6 \mathrm{~mm})$; mobile phase $80 \%$ acetonitrile, $0.1 \% \mathrm{TFA}$; gradient elution from $35 \%$ to $60 \%$ in $25 \mathrm{~min}$; flow rate: $1.2 \mathrm{ml} / \mathrm{min} ; 254 \mathrm{~nm}$; $R_{\mathrm{t}}=10.35 \mathrm{~min}$. Conditions for FTC-dodeca-penetratin and FTC-Phe ${ }^{6,14}$-penetratin: Lichrosorb 5RP 18 column $(250 \times 4.6 \mathrm{~mm})$; mobile phase $80 \%$ acetonitrile, $0.1 \%$ TFA; gradient elution from $10 \%$ to $80 \%$ in $25 \mathrm{~min}$; flow rate $1 \mathrm{ml} / \mathrm{min} ; 220 \mathrm{~nm} ; R_{\mathrm{t}}=16.18 \mathrm{~min}$ for dodeca-penetratin and $R_{\mathrm{t}}=6.92$ for Phe $e^{6,14}$-penetratin. All the FTC-peptides obtained showed a single peak (98\%) by HPLC and proved to be identical by ESI-MS (Finnigan TSQ 7000): $\mathrm{M}+\mathrm{H}^{+}=2635$ (FTC-penetratin), 2106 (FTC-dodeca-penetratin) and 2557 (FTC-Phe 6,14 -penetratin).

\section{Cell Cultures}

WC/ 1 cells are WEHI 164 murine fibrosarcoma cells transfected with the $\Delta 9$-fatty acid desaturase gene (Ole1) of Saccharomyces cerevisiae [28]. The cells were cultured at $37^{\circ} \mathrm{C}$ in a humified air environment containing $5 \% \mathrm{CO}_{2}$ in complete RPMI 1640 medium supplemented with 10\% (v/v) FCS and antibiotics. Quail fibroblasts (CEC-32; MIX-MEM/10\% FCS supplemented with $2 \%$ chicken serum), human cervix adenocarcinoma cells (HeLa; MIX-MEM/ 10\% FCS), mouse fibrosarcoma cells (L929; MIX-MEM/ 10\% FCS) and mouse macrophages (RAW 264.7; MIX-MEM/ 10\% FCS) were cultured similarly.

\section{Confocal Laser Scanning Microscopy}

L929, HeLa and RAW 264.7 cells were used to visualize the uptake of the FITC-labeled peptides by confocal laser scanning microscopy. Cells were preincubated in Opti-MEM at $37^{\circ}$ or $0^{\circ} \mathrm{C}$ for $30 \mathrm{~min}$ before incubation with the peptides. Each peptide solution was prepared at a concentration of $5 \mu \mathrm{m}$ 
in Opti-MEM by a dilution of a stock solution of peptide at $1 \mathrm{~mm}$ in PBS. After incubation with the peptides (for 15, $30,60,90,120$ and $180 \mathrm{~min}$ ) the cells were rinsed three times with ice-cold PBS and the distribution of fluorescence was immediately analysed on a Zeiss LSM 410 confocal laser scanning microscope (Zürich, Switzerland). Excitation was obtained with an argon ion laser set at $488 \mathrm{~nm}$ for fluorescein isothiocyanate excitation and the emitted light was filtered with an appropriate long pass filter $(514 \mathrm{~nm})$. Sections presented were taken approximately at the mid-height level of the cells. Photomultiplier gain and laser power were identical within each experiment. Cell viability was routinely determined using the trypan blue exclusion test to make sure that the microscopic studies were always carried out on viable cells.

\section{Flow Cytometry Assay}

L929, HeLa, RAW 264.7, CEC-32 and WC/1 cells were used to quantify the membrane translocational activity of the fluorescent peptides. Cellular uptake was measured by flow cytometry using a FACScan (Becton Dickinson). FITC-labeled peptides (at concentrations of $5 \mu \mathrm{m}$ ) were incubated with the cells above $\left(6 \times 10^{5}\right.$ cells $\left./ \mathrm{ml}\right)$ in Opti-MEM at $37^{\circ}$ and $0^{\circ} \mathrm{C}$ for various periods of time. The control cells did not receive any peptide treatment. After the incubation period the cells were washed twice and then resuspended in $0.5 \mathrm{ml}$ of ice-cold physiological saline. Equal volumes of this suspension and a stock solution of trypan blue $(500 \mu \mathrm{g} / \mathrm{ml}$ dissolved in icecold $0.1 \mathrm{~m}$ citrate buffer at $\mathrm{pH} 4.0$ ) were allowed to mix for 1 min before FACS analyses. In this way the sample $\mathrm{pH}$ was lowered to nearly 4.0, thereby optimizing the quenching effect of trypan blue [27]. A minimum of 10000 events per sample was analysed. Cell viability was determined by concurrent propidium iodide $(0.2 \mu \mathrm{g} / \mathrm{ml}$; Sigma) staining.

To investigate the involvement of cholesterol-rich membrane domains (lipid rafts) in peptide uptake, L929, HeLa and RAW 264.7 cells were pretreated with $5 \mathrm{~mm}$ methyl- $\beta$-cyclodextrin (MCD; Sigma) for $60 \mathrm{~min}$ at $37^{\circ} \mathrm{C}$ and then treated as mentioned above. To study the role of polyanionic cell-surface proteoglycans, the cells were co-incubated with heparan sulfate (HS; $25 \mu \mathrm{g} / \mathrm{ml}$ ) and one of the FITC-labeled peptides in Opti-MEM for 90 min then processed as mentioned above for the flow cytometric analyses.

\section{Metabolic and Endocytosis Inhibitor Studies}

For experiments at $0^{\circ} \mathrm{C}$, the cells were maintained for $30 \mathrm{~min}$ on ice before peptide incubation and throughout the experiments.

To induce ATP depletion, the cells were incubated for $60 \mathrm{~min}$ with $0.1 \%$ sodium azide and $50 \mathrm{~mm} 2$-deoxy-D-glucose in OptiMEM [18] prior to the addition of peptides. The internalized peptides were visualized by confocal microscopy or quantified by flow cytometry.

\section{Cell Viability Assays}

Cytotoxicity of the applied penetratin analogs was assessed by using MTS assay (CellTiter 96 AQ ${ }_{\text {ueous }}$ Non-Radioactive Cell Proliferation Assay, Promega, USA) according to the manufacturer's protocol. Briefly, HeLa cells $\left(10^{5} /\right.$ well $)$ were cultured in 96-well microtiter plates in MIX-MEM supplemented with
$10 \%$ FCS in the presence of the analogs at different concentrations $(1,10,50$ and $100 \mu \mathrm{M}$, respectively). The control cells did not receive any peptide treatment. Twenty-four hours later the cells were incubated with the MTS assay reagents and absorbance was measured at $492 \mathrm{~nm}$ by a Labsystem Multiscan MS ELISA reader.

\section{RESULTS}

\section{Confocal Microscopy}

To examine the membrane translocational ability of penetratin and its analogs, FITC-labeled peptides were added to different types of live, unfixed cells (human HeLa cells, murine L929 fibroblasts and RAW 264.7 macrophages) and were analysed by confocal microscopy at $37^{\circ}$ and $0^{\circ} \mathrm{C}$.

Penetratin was already internalized $15 \mathrm{~min}$ after its addition to the cells at $37^{\circ} \mathrm{C}$ as revealed by a visible increase in cytoplasmic fluorescence. As the internalized amount of penetratin increased the peptide appeared in the nuclei (Figure 1A). From 60 min nuclear fluorescence became dominant, reflecting the accumulation of penetratin in the nucleus (Figure 1B and $1 \mathrm{C}$ ). Both analogs (Phe $\mathrm{C}^{6,14}$-penetratin and dodecapenetratin) showed the same translocational pattern judged by detected intracellular signals. Thus the
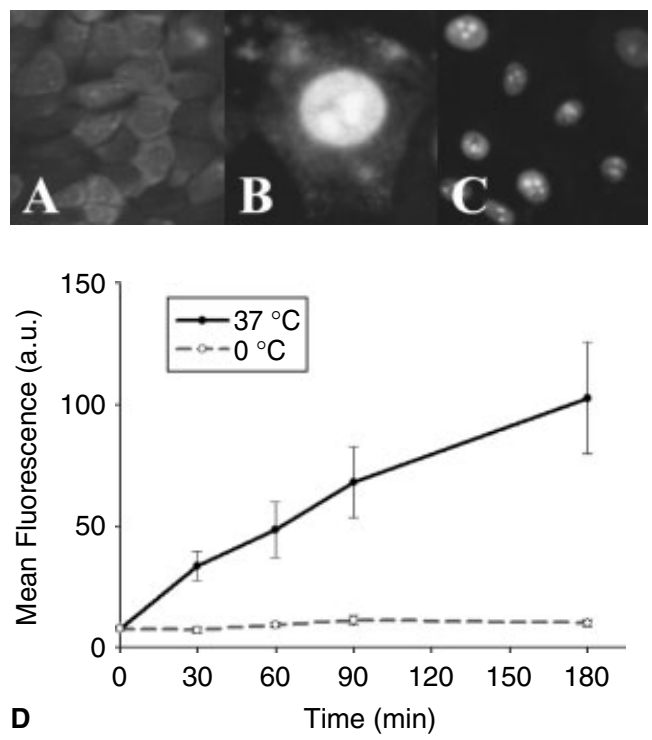

Figure 1 Internalization of penetratin into HeLa cells. HeLa cells were incubated with FITC-labeled penetratin at a concentration of $5 \mu \mathrm{M}$ and cellular uptake was analysed with confocal microscopy (A-C) and flow cytometry (D). A-C show confocal microscopic images of HeLa cells after 30 (A), 60 (B) and $120(\mathrm{C}) \mathrm{min}$ of penetratin treatment at $37^{\circ} \mathrm{C}$. D shows the quantitative flow cytometric analyses of penetratin uptake into HeLa cells at 37 and $0^{\circ} \mathrm{C}$. Extracellular fluorescence of surface bound peptides was quenched by adding trypan blue (in ice-cold $0.1 \mathrm{~m}$ citrate buffer $\mathrm{pH} 4.0$ ). Data points present mean $\pm \mathrm{SE}$ of four independent experiments. a.u., arbitrary units. For details see Materials and Methods. 
analogs were internalized very quickly and later accumulated in the nuclei at $37^{\circ} \mathrm{C}$ (data not shown). The finding that penetratin and its derivatives entered the nucleus is not surprising, since all peptides under 40-50 kDa can pass through the nuclear complex [30] and as the investigated peptides have pronounced positive charge they are attracted to the negatively charged DNA.

At $37^{\circ} \mathrm{C}$ pretreating the cells with $0.1 \%$ sodium azide and $50 \mathrm{~mm} 2$-deoxy-D-glucose for $60 \mathrm{~min}$ to deplete cellular ATP-pools inhibited the uptake of all penetratin peptides based on the lack of fluorescent signals throughout the microscopic visualizations.

At $0{ }^{\circ} \mathrm{C}$ no significant intracellular fluorescent signals were detected from cells treated with the investigated penetratin peptides, proving that none of the peptides can translocate through membranes in the frozen state.

\section{Flow Cytometry}

Flow cytometric measurements were used to quantify the cellular uptake of FITC-labeled peptides at concentrations of $5 \mu \mathrm{m}$. First the temperature dependence of cellular uptake of penetratin into HeLa cells was analysed. Extracellular fluorescence due to surface bound peptides was quenched by adding trypan blue (at a concentration of $0.25 \%$ ) $1 \mathrm{~min}$ before the analyses thus only the internalized portion of FITCpenetratin was quantified. Cellular fluorescence continually increased within the $3 \mathrm{~h}$ of detection at $37^{\circ} \mathrm{C}$. The steady low level of cellular fluorescence at $0{ }^{\circ} \mathrm{C}$ reflected a lack of cellular uptake (Figure 1D).

Next the FITC-labeled penetratin (at a concentration of $5 \mu \mathrm{M}$ ) was added to L929, HeLa and RAW 264.7 cells. Treating the cells with FTC-penetratin for $90 \mathrm{~min}$ at $37^{\circ} \mathrm{C}$ increased the cellular fluorescence in all cell lines (Figures 2A-C). The most significant increase in fluorescence was detected in RAW macrophages, a celltype with enhanced endo- and phagocytic potential (Figure 2C). When applied to the same cell lines at the same concentration $(5 \mu \mathrm{M})$ at $37^{\circ} \mathrm{C}$, both analogs induced a marked increase in cellular fluorescence similar to penetratin, however, the extent of the increase was smaller in cells treated with $\mathrm{Phe}^{6,14}$-penetratin.

ATP-depletion abolished the uptake of penetratin and its derivatives as judged by the detected low fluorescent signals from sodium azide-treated cells. Pretreating the cells with methyl- $\beta$-cyclodextrin (MCD)
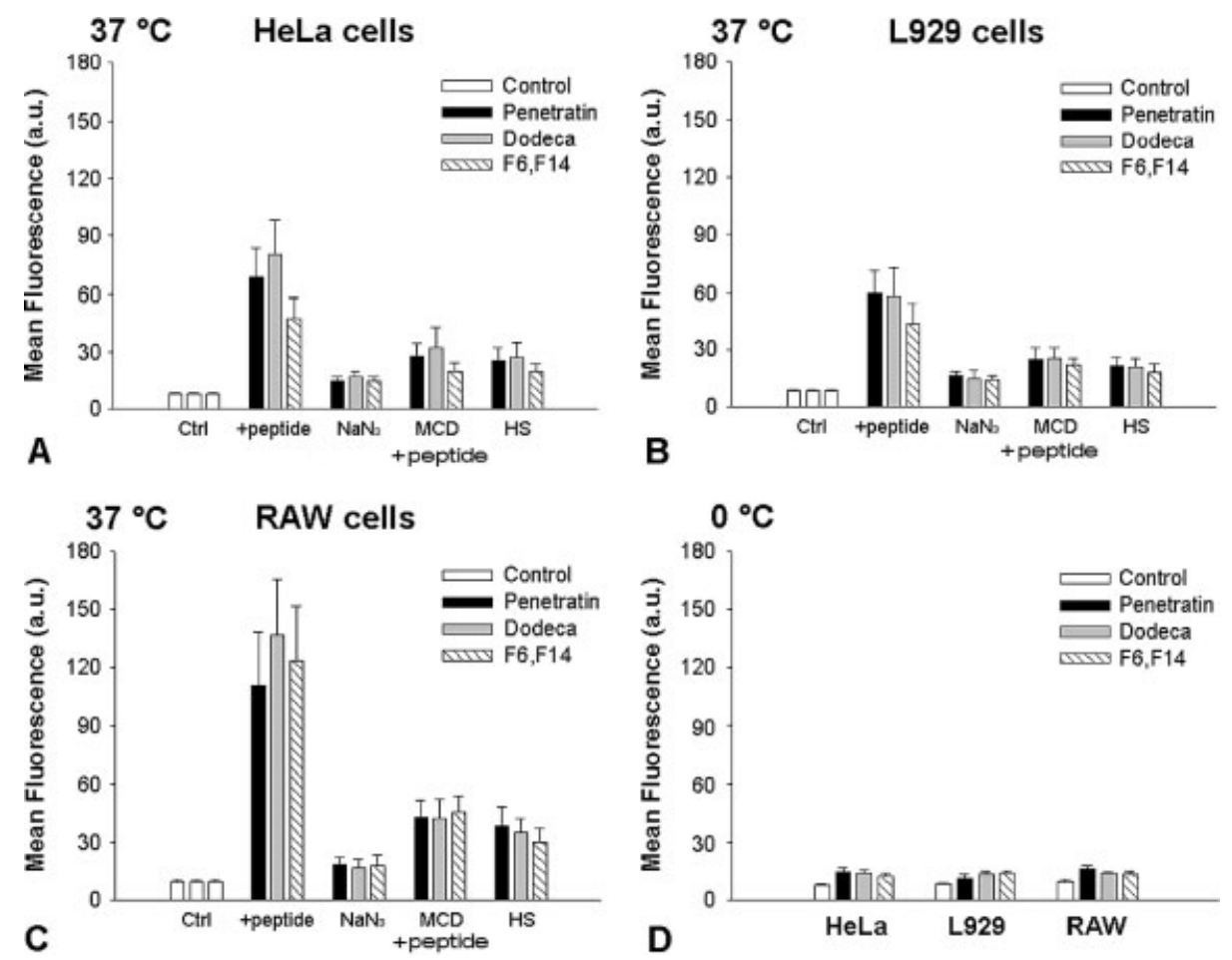

Figure 2 Flow cytometric analyses of cellular internalization of the penetratin peptides. HeLa, L929 and RAW 264.7 cells were incubated with FITC-labeled penetratin peptides ('Dodeca' $=$ dodeca-penetratin; 'F6,F 14 ' $=$ Phe $^{6,14}$-penetratin) at a concentration of $5 \mu \mathrm{M}$ for $90 \mathrm{~min}$ and cellular fluorescence was analysed by flow cytometry. Analyses on ATP-depleted cells were carried out by incubating the cells with $0.1 \%$ sodium azide (' $\mathrm{NaN}_{3}$ ') and $50 \mathrm{~mm}$ 2-deoxy-D-glucose in Opti-MEM for 60 min prior to the addition of the peptides at $37^{\circ} \mathrm{C}$. To disrupt lipid rafts some of the cells were treated with $5 \mathrm{~mm} / \mathrm{ml}$ of methyl- $\beta$-cyclodextrin ('MCD') for $60 \mathrm{~min}$ before peptide treatment at $37^{\circ} \mathrm{C}$. Other cells were co-incubated with $25 \mu \mathrm{g} / \mathrm{ml}$ of heparan sulfate ('HS') and the peptides at $37^{\circ} \mathrm{C}$. Control cells did not receive peptide treatment. A-C show the results of these quantitative flow cytometric analyses at $37^{\circ} \mathrm{C}$ and $\mathrm{D}$ shows those at $0^{\circ} \mathrm{C}$. Extracellular fluorescence of surface bound peptides was quenched by trypan blue. Error bars indicate mean $\pm \mathrm{SE}$ of four independent experiments. a.u., arbitrary units. For details see Materials and Methods. 
to deplete cholesterol from the membrane markedly inhibited the increase of cellular fluorescence and thus the cellular uptake of the peptides at $37^{\circ} \mathrm{C}$, reflecting the involvement of lipid rafts in internalization. Furthermore co-incubation with heparan sulfate (HS; $25 \mu \mathrm{g} / \mathrm{ml}$ ) greatly reduced cellular fluorescence at $37^{\circ} \mathrm{C}$, showing the importance of interactions with polyanionic surface proteoglycans in the cellular uptake of the examined cationic penetratin peptides (Figures 2A-C). According to our flow cytometric analyses, the uptake of the analogs was most significant into RAW 264.7 cells (Figure $2 \mathrm{C}$ ). At $0^{\circ} \mathrm{C}$ none of the peptide-treated cells showed a significant increase in cellular fluorescence (Figure 2D), hence demonstrating the lack of uptake at this low temperature.

Lipid raft-mediated endocytosis is greatly influenced by membrane fluidity [31]. As previous flow cytometric analyses revealed the involvement of lipid rafts in the internalization of penetratin peptides, the effect of membrane fluidity on peptide uptake was investigated as well. The uptake of the penetratin peptides was quantified on fibroblasts with different membrane fluidity. L929 murine fibroblasts have normal membrane fluidity at $37^{\circ} \mathrm{C}$. WC/1 cells are WEHI 164 murine fibrosarcoma cells transfected with the $\Delta 9$-desaturase gene [28], which renders their membrane highly fluid. CEC-32 fibroblasts are from the quail, a bird in which the physiological body temperature is around $41.6^{\circ} \mathrm{C}$, thus at $37^{\circ} \mathrm{C}$ these $\mathrm{CEC}-32$ quail fibroblasts have quite rigid membranes. Ninety minutes after the addition of peptides quite pronounced fluorescent signals were obtained from WC/ 1 cells with high membrane fluidity. On the other hand, very low levels of cellular fluorescence were measured on CEC-32 quail fibroblasts (Figure 3).

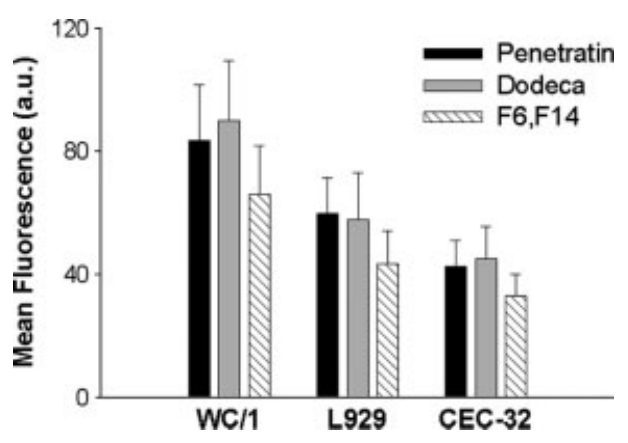

Figure 3 The effect of membrane fluidity on the translocational activity of penetratin peptides. WC/1, L929 and CEC-32 fibroblasts were incubated with $5 \mu \mathrm{M}$ of FITC-labeled penetratin and its analogs ('Dodeca'=dodeca-penetratin; 'F6,F14'= Phe $e^{6,14}$-penetratin) at $37^{\circ} \mathrm{C}$ for $90 \mathrm{~min}$ and cellular fluorescence was analysed by flow cytometry. Extracellular fluorescence of surface bound peptides was quenched by trypan blue. Error bars represent mean $\pm \mathrm{SE}$ of four independent experiments. a.u., arbitrary units. For details see Materials and Methods.
Concurrent propidium iodide staining during the flow cytometric analyses showed that none of the peptides were cytotoxic at a concentration of $5 \mu \mathrm{m}$.

The cytotoxicity of the two penetratin analogs was determined on HeLa cells by standard MTS assay. The cells were incubated with the peptides for $24 \mathrm{~h}$ at various concentrations $(1,10,50$ and $100 \mu \mathrm{m}$, respectively) at $37^{\circ} \mathrm{C}$. The MTS cell-viability assays revealed that none of the analogs were cytotoxic even at $100 \mu \mathrm{M}$ (Figure 4).

\section{DISCUSSION}

Views on the cellular internalization of the Antennapedia-derived penetratin peptide are finally being reformed. Recent studies clearly showed the endocytic nature of penetratin uptake [18-21]. Considering the evidence on endocytic uptake the study reevaluated the necessity of the two tryptophans in the sequence and the former statement that shortening the peptide impedes its membrane translocational ability [15-17]. Thus two penetratin analogs were designed and synthesized: a $\mathrm{Phe}^{6,14}$-penetratin, an analog in which the two tryptophans were replaced by phenylalanines and a shortened analog called dodeca-penetratin made up of only 12 amino acid residues. Dodeca-penetratin was produced by removing Gln8, Asn9, Arg11 and Met 12 from the penetratin sequence. Since Gln and Asn have a pronounced hydrophilic character their removal was expected to facilitate hydrophobic interactions with the membrane. The hydrophobic length of the peptide was not altered and in order to retain the cationic character the abundance of basic arginines and lysines was preserved because the basic sidechains of these residues help to attract cationic peptides to the negatively charged membrane surfaces [32,33]. It is well established that the binding affinity of

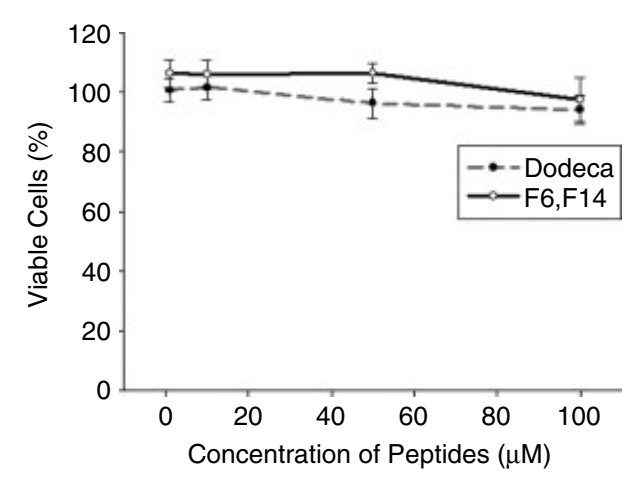

Figure 4 Effects of the penetratin analogs on cell viability. HeLa cells were incubated for $24 \mathrm{~h}$ with increasing concentrations of the two analogs ('Dodeca'=dodeca-penetratin; 'F6,F14' $=\mathrm{Phe}^{6,14}$-penetratin). Cell viability was measured following a standard MTS assay procedure. Results of four independent assays were normalized and plotted as percent of viable cells. Data points represent mean $\pm \mathrm{SE}$. 
penetratin for cellular surfaces originates from the long-range Coulombic attraction arising between the positive charges of the peptide and the negative charges of the membrane [34-37]. However, as the peptide is being drawn towards the membrane, it also experiences another non-specific electrostatic attraction due to the cation- $\pi$ interactions between the positive charges of lipids and the $\pi$ face of aromatic side chains of tryptophans and phenylalanines. Since cation- $\pi$ interactions of Phe are much weaker than that of Trp [38-40] it was interesting to examine the effect of replacing tryptophans with phenylalanines.

Comparing the translocational abilities of penetratin and its analogs, it can be stated that rational shortening of penetratin does not abolish its uptake. The similar translocational efficacy of dodeca-penetratin raises the importance of basic residues and aromatic tryptophans in the internalization of penetratin and shows that binding of these cationic peptides to the cell-surface is absolutely nonspecific. Replacing the tryptophans with phenylalanines markedly decreased internalization of the peptide. Based on these results it can be stated that the presence of Trp, probably due to the affinity of this residue to the electrostatically complex membrane interface [41], benefits the internalization of penetratin. Whether the contribution of Trp to the internalization process depends on the enhanced cation- $\pi$ interactions of Trp or whether other factors might play a role in its superiority over Phe in the translocation still remains elusive.

As inhibiting cellular metabolism with sodium azide at $37^{\circ} \mathrm{C}$ or incubating the cells at $0^{\circ} \mathrm{C}$ clearly abolished the internalization of the investigated peptides, it was demonstrated that penetratin peptides entered the cells via active, energy-dependent endocytic uptake. Endocytosis is a complex mechanism involving different pathways. The best-studied endocytic pathway involves clathrin, which forms coated membrane invaginations on the plasma membrane that recruit cell-surface receptors. Less well characterized, but equally important, are non-clathrin endocytic pathways. Clathrinindependent endocytosis includes phagocytosis, constitutive pinocytotic pathways as well as endocytosis mediated by caveolae and lipid rafts [42-44]. Lipid rafts are enriched in cell-surface proteoglycans and uptake mediated by these rafts is highly sensitive to a decrease in membrane fluidity [31]. It was clearly demonstrated that the uptake of penetratin and its derivatives is highly dependent on cell-surface polyanions and physiological values of membrane fluidity. Moreover methyl- $\beta$-cyclodextrin, an agent that disrupts cholesterol-rich lipid rafts and thus inhibits raft-mediated endocytosis, greatly diminished the internalization of the penetratin peptides. All these findings show the major role of lipid rafts in the internalization of penetratin and its derivatives. It is important to point out that, in contrast to the classic clathrindependent endocytosis, the caveolar/glycolipid raftmediated internalization seems to avoid lysosomes and hence the degradation of engulfed molecules [45]. The lack of lysosomal degradation renders lipid-raft mediated endocytosis a favorable route to deliver bioactive compounds into cells.

In summary this work provides evidence for the endocytic uptake of penetratin and demonstrates that internalization of the peptide involves lipid rafts. By binding to polyanionic cell-surface proteoglycans, the basic residues of the peptide have a major role in the internalization and probably because of their abilities for complex electrostatic interactions the presence of tryptophans is highly beneficial, but not essential, for cellular uptake.

\section{REFERENCES}

1. Langel Ü. Cell Penetrating Peptides: Processes and Applications. CRC Press: Boca Raton, FL, 2002.

2. Lundberg $P$, Langel Ü. A brief introduction to cell-penetrating peptides. J. Mol. Recognit. 2003; 16: 227-233.

3. Kabouridis PS. Biological applications of protein transduction technology. Trends Biotechnol. 2003; 21: 498-503.

4. Jarver P, Langel U. The use of cell-penetrating peptides as a tool for gene regulation. Drug Discov. Today 2004; 9: 395-402.

5. Dietz GP, Bdeltahr M. Delivery of bioactive molecules into the cell: the Trojan horse approach. Mol. Cell. Neurosci. 2004; 27: 85-131.

6. Dupont E, Joliot AH, Prochiantz A. Penetratin. In Cell Penetrating Peptides: Processes and Applications, Langel Ü (ed.). CRC Press: Boca Raton, 2002; 23-51.

7. Maruta $\mathrm{H}$, He H, Nheu T. Interfering with Ras signaling using membrane-permeable peptides or drugs. Methods Mol. Biol. 2002; 189: $75-85$.

8. Schaschke N, Deluca D, Assfalg-Machleidt I, Hohneke C, Sommerhoff CP, Machleidt W. Epoxysuccinyl peptide-derived cathepsin B inhibitors: modulating membrane permeability by conjugation with the $C$-terminal heptapeptide segment of penetratin. Biol. Chem. 2002; 383: 849-852.

9. Tseng YL, Liu JJ, Hong RL. Translocation of liposomes into cancer cells by cell-penetrating peptides penetratin and tat: a kinetic and efficacy study. Mol. Pharmacol. 2002; 62: 864-872.

10. Li Y, Rosal RV, Brandt-Rauf PW, Fine RL. Correlation between hydrophobic properties and efficiency of carrier-mediated membrane transduction and apoptosis of a p53 C-terminal peptide. Biochem. Biophys. Res. Commun. 2002; 298: 439-449.

11. Gil-Parrado S, Assfalg-Machleidt I, Fiorino F, Deluca D, Pfeiler D, Schaschke N, Moroder L, Machleidt W. Calpastatin exon 1Bderived peptide, a selective inhibitor of calpain: enhancing cell permeability by conjugation with penetratin. Biol. Chem. 2003; 384: 395-402.

12. Greenwood J, Amos CL, Walters CE, Couraud PO, Lyck R, Engelhardt B, Adamson P. Intracellular domain of brain endothelial intercellular adhesion molecule-1 is essential for $\mathrm{T}$ lymphocyte-mediated signaling and migration. J. Immunol. 2003; 171: 2099-2108.

13. Muratovska A, Eccles MR. Conjugate for efficient delivery of short interfering RNA (siRNA) into mammalian cells. FEBS Lett. 2004; 558: $63-68$.

14. Eibert SM, Lee KH, Pipkorn R, Sester U, Wabnitz GH, Giese T, Meuer SC, Samstag Y. Cofilin peptide homologs interfere with immunological synapse formation and T cell activation. Proc. Natl Acad. Sci. USA 2004; 101: 1957-1962. 
15. Derossi D, Joliot AH, Chassaing G, Prochiantz A. The third helix of the Antennapedia homeodomain translocates through biological membranes. J. Biol. Chem. 1994; 269: $10444-10450$.

16. Derossi D, Calvet S, Trembleau A, Brunissen A, Chassaing G, Prochiantz A. Cell internalization of the third helix of the Antennapedia homeodomain is receptor-independent. J. Biol. Chem. 1996; 271 : 18 188-18 193.

17. Derossi D, Chassaing G, Prochiantz A. Trojan peptides: the penetratin system for intracellular delivery. Trends Cell. Biol. 1998; 8: $84-87$.

18. Drin G, Cottin S, Blanc E, Rees AR, Temsamani J. Studies on the internalization mechanism of cationic cell-penetrating peptides. $J$. Biol. Chem. 2003; 278: 31 192-31 201.

19. Console S, Marty C, Garcia-Echeverria C, Schwendener R, BallmerHofer K. Antennapedia and HIV transactivator of transcription (TAT) 'protein transduction domains' promote endocytosis of high molecular weight cargo upon binding to cell surface glycosaminoglycans. J. Biol. Chem. 2003; 278: 35 109-35 114.

20. Letoha T, Gaal S, Somlai C, Czajlik A, Perczel A, Penke B. Membrane translocation of penetratin and its derivatives in different cell lines. J. Mol. Recognit. 2003; 16: 272-279.

21. Fischer R, Kohler K, Fotin-Mleczek M, Brock R. A stepwise dissection of the intracellular fate of cationic cell-penetrating peptides. J. Biol. Chem. 2004; 279: 12625-12 635.

22. Czajlik A, Mesko E, Penke B, Perczel A. Investigation of penetratin peptides. Part 1. The environment dependent conformational properties of penetratin and two of its derivatives. J. Pept. Sci. 2002; 8: 151-171.

23. Sahlin S, Hed J, Rundquist I. Differentiation between attached and ingested immune complexes by a fluorescence quenching cytofluorometric assay. J. Immunol. Methods 1983; 60: 115-124.

24. Bjerknes R, Bassoe CF. Human leukocyte phagocytosis of zymosan particles measured by flow cytometry. Acta Pathol. Microbiol. Immunol. Scand. 1983; 91: 341-348.

25. Bjerknes R. Flow cytometric assay for combined measurement of phagocytosis and intracellular killing of Candida albicans. J. Immunol. Methods 1984; 72 : 229-241.

26. Bjerknes R, Bassøe C-F. Phagocyte C3-mediated attachment and internalization: flow cytometric studies using a fluorescence quenching technique. Blut 1984; 49: 315-323.

27. Busetto S, Trevisan E, Patriarca P, Menegazzi R. A single-step, sensitive flow cytofluorometric assay for the simultaneous assessment of membrane-bound and ingested Candida albicans in phagocytosing neutrophils. Cytometry A 2004; 58A: 201-206.

28. Gyorfy Z, Benko S, Kusz E, Maresca B, Vigh L, Duda E. Highly increased TNF sensitivity of tumor cells expressing the yeast delta 9-desaturase gene. Biochem. Biophys. Res. Commun. 1997; 241 : 465-470.

29. Fülöp L, Penke B, Zarandi M. Synthesis and fluorescent labeling of beta-amyloid peptides. J. Pept. Sci. 2001; 7: 397-401.
30. Talcott B, Moore MS. Getting across the nuclear pore complex. Trends Cell. Biol. 1999; 9: 312-318.

31. Baba T, Rauch C, Xue M, Terada N, Fujii Y, Ueda H, Takayama I, Ohno S, Farge E, Sato SB. Clathrin-dependent and clathrinindependent endocytosis are differentially sensitive to insertion of poly (ethylene glycol)-derivatized cholesterol in the plasma membrane. Traffic 2001; 2: 501-512.

32. Kim J, Mosior M, Chung LA, Wu H, McLaughlin S. Binding of peptides with basic residues to membranes containing acidic phospholipids. Biophys. J. 1991; 60: 135-148.

33. Ben-Tal N, Honig B, Peitzsch RM, Denisov G, McLaughlin S. Binding of small basic peptides to membranes containing acidic lipids: theoretical models and experimental results. Biophys. J. 1996; 71 : 561-575.

34. Magzoub M, Eriksson LE, Graslund A. Conformational states of the cell-penetrating peptide penetratin when interacting with phospholipid vesicles: effects of surface charge and peptide concentration. Biochim. Biophys. Acta 2002; 1563: 53-63.

35. Binder H, Lindblom G. Charge-dependent translocation of the trojan peptide penetratin across lipid membranes. Biophys. J. 2003; 85: 982-995.

36. Binder $\mathrm{H}$, Lindblom $\mathrm{G}$. Interaction of the Trojan peptide penetratin with anionic lipid membranes-a caloriometric study. Phys. Chem. Chem. Phys. 2003; 5: 5108-5117.

37. Binder H, Lindblom G. A molecular view on the interaction of the trojan peptide penetratin with the polar interface of lipid bilayers. Biophys. J. 2004; 87: 332-343.

38. Dougherty DA. Cation- $\pi$ interactions in chemistry and biology: a new view of benzene, Phe, Tyr and Trp. Science 1996; 271: 163-168.

39. Mecozzi S, West AP, Dougherty DA. Cation- $\pi$ interactions in aromatics of biological and medicinal interest: Electrostatic potential surfaces as a useful qualitative guide. Proc. Natl Acad. Sci. USA 1996; 93: 10 566-10571.

40. Gallivan PJ, Dougherty DA. Cation- $\pi$ interactions in structural biology. Proc. Natl Acad. Sci. USA 1999; 96: 9459-9464.

41. Yau WM, Wimley WC, Gawrisch K, White SH. The preference of tryptophan for membrane interfaces. Biochemistry 1998; 37: 14713-14718.

42. Nichols BJ, Lippincott-Schwartz J. Endocytosis without clathrin coats. Trends Cell. Biol. 2001; 1 1: 406-412.

43. Nabi IR, Le PU. Caveolae/raft-dependent endocytosis. J. Cell. Biol. 2003; 161: 673-677.

44. Parton RG, Richards AA. Lipid rafts and caveolae as portals for endocytosis: new insights and common mechanisms. Traffic 2003; 4: $724-738$.

45. Bathori G, Cervenak L, Karadi I. Caveolae - an alternative endocytic pathway for targeted drug delivery. Crit. Rev. Ther. Drug Carrier Syst. 2004; 21 : 67-95. 